\title{
Selected Reference Books of 1971-72
}

\section{INTRODUCTION}

$\mathrm{T}$ HIS ARTICLE continues the semiannual series originally edited by Constance $\mathrm{M}$. Winchell. Although it appears under a byline, the list is actually a project of the Reference Department of the Columbia University Libraries, and notes are signed with the initials of the individual staff members. ${ }^{1}$

Since the purpose of the list is to present a selection of recent scholarly and foreign works of interest to reference workers in university libraries, it does not pretend to be either well balanced or comprehensive. Code numbers (such as AA71, 2BD89) have been used to refer to titles in the Guide to Reference Books and its supplements. ${ }^{2}$

\section{NATIONAL BibLiography}

Zimmerman, Irene. Current National Bibliographies of Latin America; a State of the Art Study. [Gainesville], Center for Latin American Studies, Univ. of Florida, 1971. 139p. \$7.00. 73-632969.

Irene Zimmerman, eminent Latin Americanist, here provides a country-by-country account of the available bibliographies of current Latin American publications. This is not an annotated bibliography, but rather "an attempt to describe the major characteristics of each individual situation and the results of what efforts are being made to produce a current record of a given country's publications."-Introd. The intro-

\footnotetext{
${ }^{1}$ Diane Goon, Rita Keckeissen, Eileen McIlvaine, Mary Ann Miller, Janet Schneider, Nancy Schroeder, Barbara Wendell; School of Library Service, Evelyn Lauer.

"Constance M. Winchell, Guide to Reference Books (8th ed.; Chicago: ALA, 1967); Supplement I (Chicago: ALA, 1968); Supplement II (Chicago: ALA, 1970).
}

duction presents a bibliographic essay about the sources applicable to Latin America as a whole before consideration is given to each country in Part II, "South America," and Part III, "The Caribbean Area." As Ms. Zimmerman defines the term, any published material which can be construed to be of aid in providing a record of a country's publications is part of its comprehensive national bibliography. "If the records include periodicals, government documents, theses, and whatever else a printing press ... can produce, so much the better."-Introd. Thus we find her book an extremely useful and comprehensive guide to bibliographic sources of Latin America. There is a selective bibliography and a good index.-M.M.

\section{BOOK REVIEW INDEXES}

Internationale Bibliographie der Rezensionen wissenschaftlicher Literatur. Hrsg. von Otto Zeller. Jahrg.1, Halbband 1- . Osnabrück, Dietrich, 1971- . Semiannual? (Jahrg.1, Halbband 1, 4 parts in 3v.) Title also in English: International bibliography of book reviews of scholarly literature.

Contents: A, Verzeichnis der berücksichtigten Zeitschriften; B, Verzeichnis der Rezensionen nach Schlagwörtern; C, Verzeichnis der Rezensionen nach rezensierten Verfassern; D, Verzeichnis der Rezensionen nach Rezensenten.

This book review index, like its predecessor Bibliographie der Rezensionen, 1900-43 (Guide AA313), is very comprehensive, covering in the first issue about 1700 scholarly journals in more than a dozen languages and in fields as varied as ecumenism and entomology, music and microbiology. Format is that of the related publication, Internationale Bibliographie der Zeitschriftenliteratur (Guide AF118), and the journals cited in part A are all from its list. This first Halbband lists reviews 
mainly of 1968-69 books, but includes many from earlier in the decade, and at least one 1960 imprint was noted in spotchecking.

Entry includes author, title, full imprint, and paging of the book; full name of the reviewer; volume, date, and paging of journal (which is cited by key number). Complete information is given in parts B, $\mathrm{C}$, and $\mathrm{D}$. The listing by reviewer, part D, is a useful feature offered by no other general book review index currently published. The work will be an important one in the large library.-R.K.

\section{MICROFORMS}

Microform Review. v.1, no.1- , Jan. 1972. Weston, Conn., 1972- . Quarterly. $\$ 30$ for journal and microfiche eds.; $\$ 20.00$ for journal ed. only; $\$ 20.00$ for microfiche ed. only.

Editor Allen B. Veaner and his advisory board of librarians and historians are to be congratulated for founding a journal addressed to the problems which librarians face in intelligently managing the proliferation of materials produced in microform. There is a great need for evaluation of "the acquisitions and servicing effects upon our collections, our bibliographic tools and our public service capabilities." $-v .1$, no.1. The new journal provides a news section for announcements of projects, indexes, and bibliographies, as well as articles of interest to scholars and librarians: "Some Problems of Microform Utilization in Large University Libraries" by C. Edward Carroll, and "Research at the London Public Record Office: a Commentary on British Foreign Office Papers and Other Collections" by Thomas E. Hachey are but two of the articles appearing in the first issue. The long reviews of microform projects are especially helpful; in addition to a description and evaluation, the reviews indicate format, quantity, durability, finding aids, reduction ratio, and replacement policy. From the point of view of the reference librarian one hopes that the journal will offer review articles on older, as well as new, microform collections.-E.M.

\section{ENCYCLOPEDIAS}

Meyers enzyklopädisches Lexikon. 9., völlig neu bearb. Aufl. Mit 100 signierten Sonderbeiträgen. Mannheim, Bibliographisches Institut, 1971- . v.1- $\quad$ \$ $\$ 24.50$ per v. (In progress) 70-873556.

Contents: v.1-3, A-Ber.

This edition, to be in 25 volumes, marks a return to the quality and standards of the long line of encyclopedias bearing the name of Meyer and published in Leipzig from 1840 until the firm's liquidation in 1945. An 8th edition, published 1936-42 and influenced by Nazi ideology, was abandoned after volume 9. Meyers neues Lexikon (8 volumes and supplement, 1961-67; Guide AD38) was published without edition number; it was characterized by numerous short articles with little or no bibliography, and strongly reflected the political orientation of the East German government. While brief entries still abound in this new edition, important topics receive very full treatment, and bibliographies are often extensive and generally up-to-date. Maps and charts accompany country articles, and there are thousands of diagrams and illustrations (both in color and black-andwhite), most of them small, but of high quality. Biographical sketches include living persons. Atlas and index volumes are promised, but are optional purchases.E.S.

\section{LANGUAge Dictionaries}

Baldinger, Kurt. Dictionnaire étymologique de lancien français. Québec, Les Presses de l'Université Laval, 1971- . fasc.1(In progress)

Contents: fasc.1, G ${ }^{1}$ (Gaaignepain-Garder). \$14.00.

Although students of Old French already have at their disposal a range of excellent dictionaries, notably Godefroy's Dictionnaire de lancienne langue française, the Tobler-Lommatzsch Altfranzösisches Wörterbuch and Wartburg's monumental Französisches etymologisches Wörterbuch (Guide AE246, AE250 and AE239, respectively), this one offers advantages that wholly justify its publication. It is based on Wartburg, but since it is restricted to the vocabulary of the mid ninth to mid fourteenth centuries, it is able to present 
each work in greater detail. It is arranged not by etymon, as is Wartburg, but by the basic word of each etymological family, so that even a beginner without previous knowledge of French etymology can easily consult the dictionary. It is broader in scope than Tobler-Lommatzsch (which covers only the literary language), and attempts to correct the many inaccuracies of Godefroy. Attestations and lexical sources are carefully documented.

A note on the publishing schedule: the dictionary will take at least ten years to complete and will appear at the rate of two fascicules a year. $\mathrm{G}-\mathrm{Z}$ will be issued first, then $\mathrm{A}-\mathrm{F}$, in order to take advantage of the revision that is now underway for the first part of the Wartburg work. Information contained in the "DEAF" will then be used to compile more specialized dictionaries, such as a "Dictionnaire inverse de l'ancien français" and a "Dictionnaire onomasiologique de l'ancien français." An abridged edition is also planned.-N.S.

\section{Periodicals}

Woodworth, David. Guide to Current British Journals. London, Library Assoc., 1970. 269p. \&5. 74-590487.

"Designed as a quick reference source for speedy identification, and publication details, of British journals" (Introd.), this work is arranged in classed subject order with an abbreviated UDC notation assigned to the headings. Although concerned with British publications (i.e., journals published in England, Wales, Scotland, N. Ireland, and the Channel Islands), some "important" journals from the Irish Republic are included. Entries are numbered sequentially, and the title/subject index is keyed to these numbers. In effect, this is a new edition of the 1962 Guide to Current British Periodicals by Mary Toase (Guide AF49).

Entries include the standard information (title, date of first issue, frequency, publisher, features such as book reviews, etc.), but they are difficult to read without frequent referral to the explanatory notes. The last element of an entry seems somewhat superfluous: including the date of the issue examined by the compiler may be an admirable attempt at documenta- tion, but it doesn't appreciably add to the utility of the directory. A useful feature is the indication of indexing in the standard British indexes and the IBZ; an appendix lists titles which carry abstracts. $-B . W$.

\section{BIOGRAPHY}

Klein, Donald W., and Clark, Anne B. Biographic Dictionary of Chinese Communism, 1921-1965. Cambridge, Mass., Harvard Univ. Pr., 1971. 2v. \$30.6912725.

The authors are to be commended for this detailed work relating the lives of the men who made the greatest impact on the Communist movement in China from 1921 to 1965 . Of the 433 major biographies, 422 were written by Klein and Clark. Nearly half of the entries are for persons elected to the Central Committee at the Seventh Party Congress in 1945 and those elected at the first and second sessions of the Eighth Party Congress (1956-58). The remaining entries comprise "martyrs," key military figures, prominent officials, and other representative leaders.

These scholarly biographies portray a man's specific organizational connections with revolutionary parties, highlight significant events in his career, and cite major speeches and writings. Bibliographic notes indicate further sources, mainly in the English language. Frequent references to other entries serve to integrate accounts of important events and organizations. The ninety-six appendices, concerned with both personal and organizational data, include information on an additional 600 persons. The "glossary-name index" (which includes Chinese characters) lists all the names in the appendices and those mentioned in the biographic sketches as well as the names of the major biographees. This valuable aid will be welcomed by scholars, journalists, government officials, and others interested in the history of the Chinese Communist Party. Along with the Biographical Dictionary of Republican China (Suppl. 2AJ14) it provides much useful material on modern China-J.S.

Notable American Women, 1607-1950; a Biographical Dictionary. Edward T. James, ed. Cambridge, Mass., Belknap 
Pr. of Harvard Univ. Pr., 1971. 3v. \$60.00. 76-152274.

Sponsored by Radcliffe College, this long-awaited work constitutes a record of more than three hundred years of women's history in America. Modeled on the $D A B$ (Guide AJ32), it is an alphabetical arrangement of 1,377 biographical sketches ranging up to ten pages in length, by writers "with special knowledge of the subject or her field."-Pref. The criterion for inclusion is stated as "distinction in [a woman's] own right of more than local significance." The one exception made is the inclusion of the Presidents' wives regardless of their own qualifications. Like the $D A B$, the dictionary interprets "American" in a broad sense; unlike the $D A B$, it has not used conventional respectability as a necessary ingredient of "distinction." Selection was limited to women who died no later than the end of 1950 , and few active careers extend beyond 1920 . Bibliographies and notes on sources follow each sketch; articles are signed in full, sometimes by well-known scholars, but no list of the more than 700 contributors is given. Both the interesting introduction by Janet Wilson James (surveying the history of women in America) and the classified list of biographies in volume 3 should prove useful. Excellence of the work raises hope that Radcliffe will plan supplementary volumes.-R.K.

\section{PHILOSOPHY}

Vasoli, Cesare, ed. Il pensiero medievale; orientamenti bibliografici. Bari, Laterza, [1971]. 301p. L.1200.

Addressed to the student of medieval thought, this bibliographic guide covers the major and minor writers, themes, and problems of medieval philosophy from Boethius through the fourteenth century, the greater portion, of course, devoted to the twelfth and thirteenth centuries. For each author treated, works are identified, editions cited, and important critical studies (books, journal articles, and contributions to Festschriften) are given; there are many annotations. In the case of major authors for whom extensive specialized bibliography exists, a few of the most important older critical works are cited, but emphasis in these sec- tions is on significant recent materials. The editor has been at pains to include traditionally "minor" figures who in recent years have been the subject of scholarly attention. A detailed table of contents substitutes for an analytic index.-R.K.

\section{RELIGION}

Berlin, Charles, comp. Index to Festschriften in Jewish Studies. Cambridge, Harvard College Library; N.Y., Ktav, 1971. 319p. \$29.50. 72-138460.

The first index to Festschriften in Jewish studies since 1937, this useful new tool lists 6700 articles in 243 jubilee volumes, all of them in the Harvard collection. It covers primarily those Festschriften devoted entirely to Jewish history and literature of all periods and places, supplementing Marcus and Bilgray's index (Guide BB 287) both by using 1937 as the starting date for coverage and by including pre1936 volumes not in the earlier work. Festschriften indexed were published in monographic series, as separates, and as special issues of periodicals. Many languages are represented, with Hebrew accounting for a large proportion of articles. Part I of the Index is an alphabetic author list of the essays, with paging, and Festschrift source indicated by name of person in whose honor published. Part II is a subject arrangement of the articles, alphabetic according to headings adapted from the Harvard List of Subject Headings Used in the Public Catalog (1964). Preceding Part I is the "List of Festschriften Indexed," arranged by name of person or institution honored, and with full bibliographical details.-R.K.

Encyclopaedia Judaica. Jerusalem, [Keter Publ. House; N.Y.], Macmillan, [1972]. 16v. il. $\$ 500$. $72-90254$.

Noteworthy as the first Jewish encyclopedia of major proportions to be published in several decades, this scholarly work has been completely compiled and published within five years. The monumental task of producing an English-language encyclopedia providing "a comprehensive picture of all aspects of Jewish life and knowledge up to the present" (Introd.) was accomplished by 300 editors and 1800 con- 
tributors, and its publication history and that of its predecessors is interestingly detailed in the introduction. In that section the editors describe the formulation of their editorial policy and the method of compilation; inconsistencies have not only been admitted, they have been enumerated.

The index to the Encyclopaedia has been designated as volume 1 in order to emphasize its central importance to the work. That volume includes the introductory material, listings of editors and their vitas, and a key to contributors' initials. Aids such as transliteration tables (for Hebrew, Yiddish, Arabic, Greek, and Russian alphabets) and supplementary lists of Israel place names and of Hebrew newspapers and periodicals serve to make the first volume a ready reference tool.

Most of the 25,000 articles are signed, with relatively short bibliographies appended; emphasis in the latter is on Englishlanguage sources (even if they are translations of classic works). The editors state that standard histories and older encyclopedias must be consulted in many cases, but owing to space considerations these are cited only when they provide "material of special significance." The volumes are well-designed and attractively bound, and the set will be a welcome addition to any library having need of a valuable twentieth-century view of world Jewry.-B.W.

\section{The Interpreter's One-Volume Commentary}

on the Bible. Charles M. Laymon, ed. Nashville, Abingdon Pr., [1971]. 1386p. \$17.50. 71-144392.

Scholars throughout the English-speaking world have participated in this effort to provide a guide to Bible interpretation for "ministers, lay, and non-professional persons engaged in studying or teaching in the church school, college students, and those who are unequipped to follow the more specialized discussions of biblical matters."-Editor's Pref. Based on the Revised Standard Version of the Bible, the lengthy, signed commentaries on the Old and New Testaments and the Apocrypha constitute the major portion of the book. These are followed by a series of general articles on biblical interpretation, geographical and historical setting, text, canon, and translation and impact of the Bible. There is a chronology, an explanation of moneys and measures, an index of scripture references, and a series of full-color maps.

The introduction to each commentary discusses the book's historical setting, sources, authorship and date, structure, point of view, etc., and concludes with a bibliography (sometimes critically annotated) of English-language sources; English translations from works in other languages are often noted. The commentaries themselves vary widely in both style and content, though the high level of scholarship and balanced point of view are evident throughout. The editors may have presumed a wider audience than will actually prove to be the case; the work is not adapted to quick reference use or casual skimming by the general reader. But as a scholarly guide for the serious student, it is a worthy addition to the "Interpreter's family" of biblical reference works.-D.G.

Williams, Ethel L., and Brown, Clifton L., comps. Afro-American Religious Studies: A Comprehensive Bibliography with Locations in American Libraries. Metuchen, N.J., Scarecrow Pr., 1972. 454p. \$12.50. 78-166072.

Compiled in response to the "pressing need for a comprehensive bibliographical guide for sources in the area of African and Afro-American religious studies" (Pref.), this long list of books and articles (about 6000 entries) published over a broad span of time will be useful both for identifying and locating materials. There are five main sections in the classified arrangement: "African Heritage," "Christianity and Slavery in the New World," "The American Negro and the American Religious Life," "The Civil Rights Movement," and "The Contemporary Religious Scene." These, in turn, are divided and subdivided by topic, by country, and by church or sect as appropriate. The detailed table of contents which substitutes for an analytic index should be studied for maximum use. Within a sub-section entries are arranged alphabetically by author; full bibliographical information is given, and at least one location noted. There are appendices of periodical titles, manuscript collections and sources consulted, and an author index.-R.K. 


\section{LFTERATURE}

Jahn, Janheinz, and Dressler, Claus Peter. Bibliography of Creative African Writing. Nendeln, [Liechtenstein], KrausThomson, 1971. 446p. \$27.50. 70-154142.

Borrowing the term "Agisymba" from Ptolemy, the compilers note that this bibliography intends to include the creative literature of all "Agisymba" or "Black Africa"-a concept not easily defined by mere geographical or racial boundaries. For example: "In South Africa the racial law clearly separates 'Bantu' and 'European' literature. In Angola and Mozambique, however, racial lines could not be drawn. Thus all writers who call themselves Angolese or Mozambikans, even though some were born in Portugal, . . . were included."-Introd.

The work is both an expansion and updating of the African section of Jahn's Bibliography of Neo-African Literature (Suppl. 1BD3), and is restricted to books and to plays which have been performed on stage; only selected secondary literature relating to the creative works is cited. The compilers have devised a rather complex system of notations, work numbers, abbreviations, etc., in an effort to make the bibliography reflect certain things about the literature which may be of interest to the scholar. For the research worker venturing into these largely uncharted regions this should be a welcome guide. Let him acquaint himself with the "Instructions for Use," however, before he begins; it will be time well spent.-M.M.

Köttelwesch, Clemens. Bibliographisches Handbuch der deutschen Literaturwissenschaft, 1945-1969. Frankfurt am Main, V. Klostermann, 1971- . Lfg.1. DM 36.50 per Lfg. (In progress)

This is the first installment of a projected set of about ten volumes that will presumably cumulate and supplement Eppelscheimer and Köttelwesch's Bibliographie der deutschen Literaturwissenschaft (Guide BD562). It will be a select bibliography of works on German literature-books, articles, contributions to collections, theses, and reprints of books originally published before 1945-drawing principally on French and English sources to augment the German listings; however, Russian, Polish, Dutch, and Italian sources are at least represented. A wide range of journals is indexed, covering not only literature, but related materials in history, philosophy, and religion. The subject arrangement is so refined that it is not at all difficult to find articles on specific topics, even though there will be no author or subject index until the set is complete. There are no annotations, but full bibliographic information is provided.-N.S.

Lang, David Marshall, ed. A Guide to Eastern Literatures. London, Weidenfield and Nicolson, [1971]. 501p. $\& 4.25$. 75-866509.

Thanks to this admirable guide, Eastern literatures need no longer be inscrutable to the Western reader, for here he has ready access to the historical and social background, the individual works, and the interpretation of eighteen Oriental literatures. "Oriental" and "Eastern" are not limited to a geographical interpretation: Jewish, Armenian, Georgian, and Ethiopic literatures are discussed, as well as Arabic, Indian, Chinese, and Japanese. The chapter on each literature includes historical background, a survey of the main literary trends, a brief description of individual authors and their works, and a general bibliography; available English translations are noted. There is an index of authors, titles, and subjects.

Mr. Lang has done fine editorial work in making a cohesive whole of so many parts; only the Indian and Pakistani literature section seems too brief in its notes on individual authors. Overall, the quality of the essays (by scholar specialists) is high, and that on Japanese literature is excellent.-D.G.

Rees, Robert A., and Harbert, Earl N., eds. Fifteen American Authors Before 1900; Bibliographic Essays on Research and Criticism. Madison, Univ. of Wisconsin Pr., [1971]. 442p. \$12.50. 77-157395.

Woodress, James, ed, Eight American Authors; a Review of Research and Criticism. Rev. ed. N.Y., Norton, [1972]. 392p. \$11.95. 73-160485.

By a happy coincidence, Rees and Harbert's new volume appears almost simul- 
taneously with the new edition of Eight American Authors, a work whose plan and purpose it emulates. Now, with these two volumes and Jackson Bryer's Fifteen Modern American Authors (Durham, 1969), we have good, reasonably up-to-date assessments of research and criticism of a substantial number of major American literary figures.

In the Rees-Harbert work individual scholars have contributed bibliographic essays on Henry Adams, William Cullen Bryant, James Fenimore Cooper, Stephen Crane, Emily Dickinson, Jonathan Edwards, Benjamin Franklin, Oliver Wendell Holmes, William Dean Howells, Washington Irving, Henry Wadsworth Longfellow, James Russell Lowell, Frank Norris, Edward Taylor, and John Greenleaf Whittier. In addition, there are survey chapters on the literature of the old South and of the New South. The Woodress volume again treats Poe, Emerson, Hawthorne, Thoreau, Melville, Whitman, Twain, and Henry James. Some of the essays are by the same contributors as to the 1956 edition by Floyd Stovall (Guide BD220), whereas others have been written by new scholar specialists. Attention is given to published bibliographies, editions, biographies, and critical studies. Both volumes are indexed.-E.S.

Russkie pisateli; biobibliograficheskii slovar. Moskva, Prosveshchenie, 1971. 728p. 3r., $1 \mathrm{k}$.

This attractive volume contains about 300 biographies of Russian writers from the medieval period to the early twentieth century. The signed articles, which range in length from half a page to fourteen pages (for Tolstoi), emphasize the subject's literary career and the place of his works in the history of Russian literature. Brief bibliographies at the end of each biography list the most recent editions of the authors' works, as well as a selection of books and articles about them. Almost all references are to Russian-language publications, some as recent as 1969 . Coverage of relatively minor figures is better than in the Bol shaia sovetskaia entsiklopediia (Guide AD $60)$ or the Literaturnaia entsiklopediia (Guide BD903). Since the articles are evaluative as well as factual, the dictionary is particularly interesting to American students as an expression of the current Soviet opinion of the writers included.-N.S.

Starnawski, Jerzy. Warszat bibliograficzny historyka literatury polskiej (na tle dyscyplin pokrewnych). [Wyd.2. Warszawa], Państwowe Wydawnictwo Nawkowe, [1971]. 562p. zł. 80.

The unique quality of this work lies in its being a compendium of bibliographic essays dealing with a whole range of subjects that might be of use or interest to the literary historian. Coverage is very wide, ranging from the obvious for a work of this type (history of bibliography, literary bibliography, lexicography, philology) to the truly tangential (ethnography, science, education, philosophy). A sophisticated tool geared to the use of graduate students and scholars, its emphasis is on Polish culture, but the comparative view is encouraged by several sections devoted to western literature and frequent mention throughout of foreign publications, institutions, and activities. The most recent citations are dated 1969, while retrospectively the work has no specific cut-off date. An interesting observation on editorial policy is the relative absence of reference to materials from the postwar Stalinist era. Access to the contents of the handbook is through a very detailed table of contents and an index of names and anonymous titles.-E.L.

Stratman, Carl Joseph; Spencer, David G.; and Devine, Mary Elizabeth. Restoration and Eighteenth Century Theatre Research: a Bibliographical Guide, 19001968. Carbondale, Ill., Southern Illinois Univ. Pr., [1971]. 811p. \$25.00. 71112394.

In 1969 Father Stratman and associates published Restoration and 18th Century Research Bibliography, 1961-1968, a cumulation of the annual bibliographies appearing in the journal Restoration and 18th Century Theatre Research. This new publication, a cooperative effort of a group of scholars, extends the period of coverage backward to provide a comprehensive listing of twentieth-century research in the field. Spot-checking indicates that the earlier bibliography is effectively superseded, with some revisions and improvements in 
matters of classification. As in the earlier work, an alphabetical subject arrangement is employed, but within subject categories the listing is now chronological by date of publication. In all, there are more than 6,500 entries under some 780 subject headings. An index of names (both as authors and as subject) is provided, but in virtually microscopic print. The 1968 closing date in the title is deceptive (evidently referring to publication date of the journal bibliography which will continue to serve as a supplement) since coverage in all categories checked is through 1967 only.-E.S.

Zell, Hans M., and Silver, Helene, comps.

A Reader's Guide to African Literature.

N.Y., Africana Pub. Corp., [1971]. 218p.

il. \$7.50. 76-83165.

A valuable addition to the growing reference collection on creative African literature, this work consists of annotated bibliographies (mainly of in-print titles) and a biographical dictionary of contemporary black African authors from south of the Sahara who write in English or French. The main section, an author bibliography of fiction, drama, poetry, and criticism, is subdivided into (1) English works, and (2) French or English translations from French; each part is arranged by country, then alphabetically by author. Entries are serially numbered, and give author, title, full imprint, paging, and price. Descriptive annotations often include quotations from critical reviews, together with citations to their sources. There are other annotated lists of bibliographies, critical works, anthologies, children's books, "Politically Committed Literature in English" compiled by GideonCyrus M. Mutiso, and "Some Articles on African Literature" contributed by Barbara Abrash. Fifty-one biographical sketches of important African authors form the second part of the book. An index adds to usefulness.-R.K.

\section{Social ScIences}

Mitchell, Brian R., and Jones, H. G. Second Abstract of British Historical Statistics. Cambridge, [Eng.], University Pr., 1971. 227p. \$11.50. 72-128502.

Although Mitchell and Deane's Abstract of British Historical Statistics (Guide CG
108) appeared in 1962, most of the tables in that volume did not extend beyond 1938. This new compilation is meant to serve as a continuation of the earlier volume "and so far as possible series for 1938 onwards are linked to those given in that work; but it is also a supplement containing new series."-Pref. These latter series not only include new tables for data not recorded before 1938, but also some from earlier periods which had to be omitted from the 1962 volume. Sources of the statistics are cited, but bibliographies were deemed unnecessary for the post-1938 period and references to secondary studies are only occasionally given in the introductory notes to the sections.-E.S.

Population Index Bibliography; Cumulated 1935-1968, by Authors and Geographical Areas. Boston, G. K. Hall, 1971. 9v. $\$ 745$.

Contents: Author index, 1935-1968, 4v.; Geographical index, 5v. (v.1-3, 1935-1954; v.4-5, 1954-1968) .

The Office of Population Research at Princeton has maintained card files of the bibliographic entries published in Population Index (Guide CG13) since 1935. These files, one for authors, another for geographical and topical entries, have been photographed and published in book form with very little editing. Of the two divisions, the author index will require the more cautious use. Here an item is cited only once, so one finds no added entries for joint authors or for individuals responsible for publications issued by institutions. The entry itself may also pose a problem, for names were not standardized and different transliteration schemes, for example, have sometimes been used for the same name. In the geographical index entries are arranged by continent, then by country or region, with further subdivision by topics if there are more than 100 entries. A detailed table of contents or the use of running heads would have greatly facilitated searching. A further word of caution: in 1955 the classification system was reworked, and the geographical volumes are in two sequences: 1935-54 and 1954-68.

Despite reservations, the librarian and the researcher will be pleased by the time- 
saving advantage of the cumulation, for the editors have interpreted population studies broadly and have indexed material of interest to all social scientists. Libraries will, of course, want to retain the original volumes of Population Index, since these include valuable survey articles, tables, and special studies which are indexed in the cumulated bibliography.-E.M.

\section{History and Area Studies}

Griffin, Charles C., ed. Latin America; $a$ Guide to the Historical Literature. Austin, Publ. for the Conference on Latin American History by Univ. of Texas Pr., [1971]. 700p. \$25.00. 71-165916.

A selective, scholarly bibliography of Latin American history, "the aim [of this guide] has been to give those who are beginning the serious study of Latin American history a basic tool of research that will introduce them to the most important sources and histories."-Introd. In addition to more recent materials, the work is designed to cover historiographical writings predating the inception of the Handbook of Latin American Studies in 1935; the Handbook must, of course, still be consulted to supplement and update this guide.

Entries are grouped in seven chapters, without cross references. Topical chapters of reference works, general items which do not fit into the other sections, and basic background works of precolonial history precede the most important sections on "Colonial Latin America," "Independence," and "Latin America since Independence." Here entries are arranged chronologically within geographic area. A final chapter deals with materials on inter-Hispanic American relations since 1830. Compilation has been a cooperative effort of many scholars, and descriptive annotations are generally written by the editor of each chapter. Coverage is through 1966 and includes books, periodicals, and periodical articles. The detailed table of contents serves in lieu of a subject index; an author index is provided. This is a useful compilation for the researcher in Latin American history.-J.S.

Higham, Robin, ed. A Guide to the Sources of British Military History. Berkeley,
Univ. of California Pr., 1971. 630p. \$22.50. 74-104108.

"Sponsored by the Conference on British Studies."-title page.

Twenty-five scholar specialists have here contributed bibliographic essays on the whole range of British military history from earliest times to the present. Attention is given to general histories, bibliographies, selected special studies, and sources. Each chapter includes a section on research opportunities, pointing out areas where initial research is needed or where reappraisals are in order. Mention is also made of archives and special collections of papers and documents, with suggestions on how to obtain access to them. There is no general index, but since full citations to the works discussed appear in a numbered sequence at the end of each essay (and are referred to by numbers in the text) a bibliographic search is not really difficult. There is a wealth of material here for the historian in this field.-E.S.

Nunn, Godfrey Raymond. Asia: $a$ Selected and Annotated Guide to Reference Works. Cambridge, Mass., M.I.T. Pr., 1971. 223p. \$12.50. 77-169004.

In this "first attempt to present .... a selection of the whole [reference] literature on Asia, without distinction as to place of publication, language of publication or language of materials surveyed" (Pref.) the compiler has emphasized English-language sources for modern Asia. Thus, two-thirds of the 975 titles are in English, with the remainder in Japanese, Chinese, and in other western languages. Materials dealing with the Near East and Soviet Asia are not included. The cut-off date for publications was Fall 1970.

A geographical approach is used, providing an interesting comparative review of the reference sources for each country. Encyclopedias, handbooks, directories, yearbooks, dictionaries, statistical sources, atlases, gazetteers and chronologies are noted. The annotations are excellentclear, concise, and often critical. Future editions would be enhanced by the inclusion of more titles in the humanities; there is a particular dearth of fine arts sources. Also, access to entries would be made more 
direct by a subject approach in the index. $-D . G$.

Sedgwick, Romney. The House of Commons, 1715-1754. Publ. for the History of Parliament Trust. N.Y., Oxford Univ. Pr.; London, H.M.S.O., 1970. 2v. \$70.00. 79-591358.

At head of title: The History of Parliament.

Contents: v.1, Introductory survey, appendices, constituencies, Members A-D; v.2, Members E-Z.

This second installment of the proposed biographic history of the Westminster Parliament from 1264 to the present closely resembles the previously-published (1964; Guide CI129) House of Commons, 17541790 by the late Sir Lewis Namier and John Brooke. Due to the different political situation the introductory surveys have here been changed to include an account of procedure and descriptions of the Whig government and that of the Tories; an index for these sections is included. Various appendices are followed by a section on constituencies which indicates the number of voters in each county, names of elected officials, and brief notes on local politics.

The remainder of the work is devoted to biographies of the Members of the House of Commons for the period. Limitations of time and space resulted in primarily political biographies. Basic details of each Member's life and career plus a brief survey of his political activity in Parliament constitute an entry. Flaws can always be found, such as the lack of cross references either to the Namier-Brooke volumes or to the introductory surveys, but viewed as a whole this is a carefully edited work of great value, especially for its treatment of lesser known men. Entries are signed and reference sources are noted.J.S.

\section{History OF SCIENCE}

Isis. Isis Cumulative Bibliography; a Bibliography of the History of Science Formed from Isis Critical Bibliographies 1-90, 1913-65. Magda Whitrow, ed. [London], Mansell in conjunction with the History of Science Society, 1971. 2v. $£ 28$.

Contents: v.1, Personalities, A-J; v.2,
Personalities, $\mathrm{K}-\mathrm{Z}$ and Institutions, $\mathrm{A}-\mathrm{Z}$.

These two volumes are the first parts of a larger project which will provide various subject approaches to the listings appearing in the "critical bibliographies" published in the periodical Isis, 1913-65. "Part I: Personalities contains, in alphabetical sequence, entries (references to books, monographs, pamphlets, and articles) dealing with the life and work of an individual . . . and also new editions of his work. . . P Part II: Institutions contains entries dealing with the history and work of institutions and societies."-Introd. While it does not purport to be a fully comprehensive guide to the literature of the history of science, the compilation probably provides more extensive and detailed coverage than is available elsewhere. (A few significant omissions were corrected, but no concentrated effort was made to fill gaps.) Explanatory or descriptive notes accompany some citations, and reviews of books are frequently noted.

In the further parts planned, entries will be arranged first by periods and civilizations, subdivided by subject, and finally according to topical subjects. The work will also serve as an analytical index to Isis itself, since during most of its history articles in that magazine have been treated in the critical bibliographies.-E.S.

\section{SyMBOLS}

Shepherd, Walter. Shepherd's Glossary of Graphic Signs and Symbols. London, Dent; New York, Dover, 1971. 597p. \$15.00. 71-16884.

An immensely comprehensive and meticulous work, the fruit of 23 years of labor, this volume gains and suffers by being organized in a series of tables-more than 400 of them-which follow affinity of shape, not the particular topics of abbreviation. Once one has mastered the process of interrogation, one is able to locate wholly unfamiliar symbols even if no clue is provided by the context; but it is exasperating to know to what category the symbol belongs, and still have to run it down through an elaborate analysis of its curves, lines, and dots. A topically arranged appendix gives alphabetical lists of the more important signs of the various disciplines. It 
might have doubled the length of the book, but halved the expense of time and patience, to have included complete lists of each set of symbols. Researchers in a familiar, well-defined area of study will probably find specialized dictionaries such as those edited by David D. Polon (Suppl.
1EI12, 1EG2) easier to use. Readers who encounter a mysterious symbol in an unfamiliar context, however, may well find that Shepherd's book, covering topics that range from botany to pottery marks to Arabic script, is the only one that can answer their need.-N.S. 